\title{
What a Waste! Developing the Food Waste-Preventing Behaviors Scale - A Useful Tool to Promote Household Food Waste-Prevention
}

\author{
Karolin Schmidt* \\ Department of Psychology, Otto von Guericke University, Magdeburg, Germany
}

"Corresponding author: Karolin Schmidt, Institute for Psychology Otto-von-Guericke-University, Magdeburg, Germany; E-Mail: Karolin.Schmidt@ovgu.de

\begin{abstract}
By causing high amounts of household food waste, German households contribute significantly to serious global threats for the environment. Unfortunately, current information campaigns, conducted by several food waste-prevention initiatives, often lack in recipient's perceived relevance of provided recommendations on how to prevent household food waste by improving the performance of relevant food waste-preventing behaviors. Therefore, an efficient (online) tool/ measuring instrument (the food waste-preventing behaviour scale) was developed in order to improve the effectiveness of these information campaigns.

By conducting two preliminary studies $\left(\mathrm{N}_{\mathrm{t} 1}=217 ; \mathrm{N}_{\mathrm{t} 2}=206\right)$ and examining data with exploratory factor analyses an initial version of the food waste-preventing behaviors scale (consisting of 14 items) was composed and evaluated regarding relevant scale characteristics. Due to some limitations and opportunities for further optimization of this initial version regarding these characteristics, a third study $\left(\mathrm{N}_{\mathrm{t} 3}=312\right)$ was conducted. In order to extend as well as to consolidate the initial scale-version, additional items were integrated and examined by another factor analysis. Based on this procedure, a developed version of the food waste-preventing behaviors scale - containing 21 items, seven subscales and characterized by satisfying scale characteristics - could be proposed.

Apart from some limitations, the developed scale can be assumed to have relevant implications for food waste-prevention initiative's practical work as well as for future research on household food waste-prevention.
\end{abstract}

Received Date: May 19, 2016

Accepted Date: July 01, 2016

Published Date: July 06, 2016

Citation: Schmidt, K. What a Waste! Developing the Food Waste-Preventing Behaviors Scale - A Useful Tool to Promote Household Food Waste-Prevention. (2016) Int J Food Nutr Sci 3(3): 1- 14.

DOI: $10.15436 / 2377-0619.16 .014$

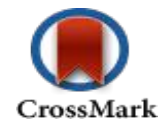

\section{Introduction}

\subsection{The problem of household food waste}

Globally, 1.3 billion tons per year of all food that is produced for human consumption are wasted ${ }^{[1-7]}$. Except for economic and social issues, these high amounts of unconsumed food also greatly contribute to global environmental problems, e.g. climate change (for example, by causing 3,3Gt unnecessary greenhouse gas emissions in 2007), water scarcity as well as increasing deforestation and species extinction ${ }^{[8]}$.

Furthermore, it should be noted, that especially industrialized countries are characterized by high amounts of food waste, i.e. food that is discarded being suitable for human consumption ${ }^{[1,2,4,7-10]}$. In consequence of inadvertence or conscious decisions for discarding, food waste - especially household food waste - is closely related to individual behavior of private consumers ${ }^{[2,4,6,7,8,10]}$. Thereby, studies conducted in several (industrialized) countries (e.g. Germany, Great Britain, USA etc.) unanimously indicated private households as main contributors of food waste ${ }^{[1,4,5,6,9,11]}$. Focusing on Germany, households are assumed to cause $61 \%$ of all food wastage, resulting in nearly 6.7 million tons per year and an average amount of $82 \mathrm{~kg}$ per person. Out of these $82 \mathrm{~kg}$, nearly $47 \%$ (i.e. $38 \mathrm{~kg}$ ) represent food that was completely edible to that time when it was discarded or it would have been edible by consumption in time ${ }^{[12]}$. Therefore, appropriate intervention approaches are needed in order to prevent these high amounts of household food waste 


\subsection{Appropriate intervention approaches to promote household food waste-prevention}

1.2.1 Predictors of household food waste-prevention: Identifying appropriate intervention approaches to promote household food waste-prevention generally depends on considering relevant influencing factors that are, somehow, causing or related to household food waste (i.e. predictors of household food waste). Consequently, these predictors will also determine household food waste-prevention. Thereby, household food waste as well as its prevention is influenced by a variety of different perceptual (e.g. perceived environmental consequences of household food waste or the perceived own ability to prevent $\mathrm{it}^{[13,14]}$ motivational. (e.g. social/ moral norms to prevent household food waste ${ }^{[14-19]}$ and behavioral predictors ${ }^{[14,20]}$. Focusing on behavioral predictors, an important aspect has to be mentioned: Household food waste as well as its prevention cannot be seen as (the result of) a single behavior, but as a combination of multiple behaviours influencing its likelihood ${ }^{[6,7,14,21,22]}$. Thereby, these food waste-related, or as termed by Schmidt (2016) food waste-preventing behaviours, represent an extensive class of different behaviours reaching from preparation of grocery shopping to grocery shopping itself, storing and preparation of food at home as well as to its final discarding.

Understanding household food waste-prevention as the result of performing several relevant food waste-prevention behaviours has important practical implications already considered by existing food waste-prevention initiatives (e.g. "Zu gut für die Tonne” [https://www.zugutfuerdietonne.de/] in Germany and „Love Food Hate Waste“ in Great Britain [http://www.lovefoodhatewaste.com]). Thereby, these initiatives are considering the meaning of performing relevant food waste-preventing behaviours sufficiently for promoting household food waste-prevention by providing appropriate action knowledge ${ }^{[23-25]}$. i.e. recommendations on how to prevent household food waste by improving the performance of relevant food waste-preventing behaviours, as an essential part of their information campaigns. From a psychological perspective, providing appropriate action knowledge built on the assumption, that knowledge and skills related to the desired behavior (i.e. household food waste-prevention) will reduce its perceived difficulty and increases the perceived ability to do $\mathrm{so}^{[26]}$. Typically, existing food waste-prevention initiatives are presenting comprehensive collections of many relevant food waste-preventing behaviours on their websites, in information brochures etc. Assuming that most people already perform at least some relevant food waste-preventing behaviours sufficiently, most recipients will only perceive some of all provided recommendations (i.e. those referring to relevant food waste-preventing behaviours a person is not performing (sufficiently)) as relevant, while others are perceived as redundant. But without considering these individual perception processes, desired effects of providing action knowledge (i.e. people are following the presented recommendations and will improve their performance of relevant food waste-preventing behaviours) becomes (more) improbable. To explain this assumption in more detail, we have to consider some insights referring to human information processing.

\subsubsection{The relevance of human information processing depth for sustainable intervention effects}

Considering established dual process models of human information processing like the elaboration likelihood model (ELM) of persuasion ${ }^{[27,28]}$ or the heuristic-systematic model of information processing ${ }^{[29,30]}$ depth of human information processing depends on the cognitive ability as well as on the individual motivation for a deep information processing. Except for other influencing factors ${ }^{[31]}$, the individual motivation highly depends on the perceived relevance of the information a person should process (e.g. a list of recommendations on how to prevent household food waste by improving relevant food waste-preventing behaviours). This is because humans can be seen as ,economy-minded souls“"[30] that are interested in processing information as most efficiently, or in other words, with at least efforts as possible (least effort principle ${ }^{[30]}$ ). Therefore, recipients of lists containing a lot of information - perceived as only partly relevant - could be less motivated to process all provided information deeply. But without such deep information processing, desired changes of recipient's attitudes or even desired changes in behavior will become not only less probable, but also less durable $\mathrm{e}^{[27-29,31-33]}$.

Therefore, promoting household food waste-prevention by providing appropriate action knowledge should be based on high probabilities for deep information processing. Thus, increasing the perceived relevance of such provided action knowledge, for example by strictly limiting to recommendations referring to relevant food waste-preventing behaviours a person (still) not perform (sufficiently), could be a useful way for existing as well as for future food waste-prevention initiatives to (further) promote household food waste-prevention sustainably “(1)”.

Therefore, the central aim of the current research study was to propose an efficient (online) tool/ measuring instrument that can be used by food waste-preventing initiatives for increasing the perceived relevance of their provided action knowledge in order to sustainably promote (further) household food waste-prevention. In this context, „efficient“"means the developed tool/ measuring instrument can be easily implemented by initiative's information campaigns (e.g. by adding the tool on websites). Additionally, reducing efforts for using the developed tool/ measuring instrument was not only applied to initiative's perspective, but also to their recipient's perspective: Thus, a tool/ measuring instrument should be developed, that allows increasing the perceived relevance of provided action knowledge without needing high recipient's efforts (e.g. by asking an excessive amount of detailed questions regarding their current performance of relevant food waste-preventing behaviours).

To fulfil this central aim, two preliminary studies were conducted in order to develop and evaluate an initial version of the desired tool/ measuring instrument (i.e. the food waste-preventing behaviours scale). Due to some limitations and opportunities for further optimization of this initial version regarding relevant scale characteristics, a third study was conducted in order to extend as well as to consolidate the initial scale-version and to finally propose a developed version of the food waste-preventing behaviours scale. 
Household Food Waste-Prevention

\section{Preliminary Studies for Developing an Initial Version of the Food Waste-Preventing Behaviours Scale}

\subsection{Materials and methods}

2.1.1 Data collection and sample recruitment: Initial development and examination of the food waste-preventing behaviours scale was realized by conducting two consecutive data collections using an online-survey implemented in LimeSurvey-software."(2)" The first assessment (t1) was conducted in September/ October 2014, the second one (t2) in December 2014/ January 2015. For both assessments, participants were recruited in Germany, mainly around the town of Magdeburg: Thereby, participants were recruited through social networks (i.e. Facebook), circular mails/ newsletters (around the university and the technical college of Magdeburg and some universities beyond) and through posters and flyers (placed or distributed at the university of Magdeburg). Furthermore, in order to receive a sample as heterogeneous as possible to avoid examining only a special household type (e.g. students' households), written invitations were also distributed through articles published in local newspapers and several people were also invited personally by presenting the intervention study on a public event concerning food waste issues in Germany, organized in the town of Magdeburg.

Initially, 336 people took part in the $\mathrm{t} 1$-assement and 279 people took part in the $\mathrm{t} 2$-assessment. After eliminating persons, who did not answer the whole online-survey, 217 people formed the final t1-sample and 206 people formed the final t2-sample. Unfortunately, regarding several socio-demographic characteristics (e.g. distributions of gender, age, education, income and household size) both samples were not representative for the German population ${ }^{[34-36]}$ (see Table 1 for details).

Table 1: Socio-demographic characteristics of $\mathrm{t} 1-(\mathrm{Nt} 1=217)$ and $\mathrm{t} 2-(\mathrm{Nt} 2=206)$ sample compared to German population.

\begin{tabular}{|c|c|c|c|c|}
\hline & t1-sample (\%) & t2-sample (\%) & \multicolumn{2}{|c|}{ German population (\%) } \\
\hline \multicolumn{5}{|l|}{ Gender } \\
\hline Male & 10.1 & 16.1 & \multicolumn{2}{|c|}{49.0} \\
\hline Female & 89.9 & 83.9 & \multicolumn{2}{|c|}{51.0} \\
\hline \multicolumn{5}{|l|}{ Age } \\
\hline$<25$ & 45.6 & 43.9 & \multicolumn{2}{|c|}{23.8} \\
\hline $25-40$ & 37.3 & 41.5 & \multicolumn{2}{|c|}{18.3} \\
\hline $40-60$ & 15.2 & 12.0 & \multicolumn{2}{|c|}{30.7} \\
\hline $60-65$ & 0.5 & 2.0 & \multicolumn{2}{|c|}{6.3} \\
\hline$>65$ & 1.4 & 1.0 & \multicolumn{2}{|c|}{20.8} \\
\hline \multicolumn{5}{|l|}{ Education } \\
\hline Higher education entrance qualification & 43.9 & 43.8 & \multicolumn{2}{|c|}{31.1} \\
\hline University degree & 46.3 & 46.8 & \multicolumn{2}{|c|}{20.1} \\
\hline Secondary education & 3.3 & 2.0 & \multicolumn{2}{|c|}{68.6} \\
\hline No graduation & 0.5 & 0.5 & \multicolumn{2}{|c|}{3.6} \\
\hline \multicolumn{5}{|l|}{ Occupation } \\
\hline Employed & 29.5 & 25.7 & \multicolumn{2}{|c|}{95.3} \\
\hline Unemployed & 1.8 & 1.0 & \multicolumn{2}{|c|}{4.7} \\
\hline Student & 60.8 & 67.5 & \multicolumn{2}{|c|}{3.3} \\
\hline Retired & 1.4 & 1.0 & \multicolumn{2}{|c|}{20.8} \\
\hline Marginally employed & 5.1 & 3.4 & \multicolumn{2}{|c|}{0.04} \\
\hline Homemaker & 2.8 & 1.9 & \multicolumn{2}{|c|}{ no data available } \\
\hline \multicolumn{3}{|l|}{ Income } & \multicolumn{2}{|c|}{ Income (deviating Scale) } \\
\hline$<€ 800$ & 55.1 & 58.8 & $<€ 900$ & 10.7 \\
\hline$€ 800-€ 1500$ & 16.4 & 20.1 & $€ 900-€ 1300$ & 13.1 \\
\hline$€ 1501-€ 2000$ & 12.1 & 10.3 & $€ 1300-€ 1500$ & 7.1 \\
\hline$€ 2001-€ 2500$ & 9.2 & 6.2 & $€ 1500-€ 2000$ & 15.8 \\
\hline$€ 2501-€ 3000$ & 1.9 & 1.5 & $€ 2000-€ 2600$ & 14.9 \\
\hline$€ 3001-€ 3500$ & 2.4 & 1.0 & $€ 2600-€ 3200$ & 10.8 \\
\hline$€ 3501-€ 4000$ & 1.4 & 1.0 & $€ 3200-€ 4500$ & 14.0 \\
\hline$€ 4001-€ 5000$ & 0.5 & 0.5 & $€ 4500-€ 6000$ & 6.5 \\
\hline$>€ 5000$ & 1.0 & 0.5 & $>€ 6000$ & 4.2 \\
\hline \multicolumn{5}{|l|}{ Household size } \\
\hline 1 person & 20.3 & 11.7 & \multicolumn{2}{|c|}{40.8} \\
\hline 2 persons & 35.0 & 75.2 & \multicolumn{2}{|c|}{34.4} \\
\hline
\end{tabular}


Household Food Waste-Prevention

\begin{tabular}{|l|c|c|c|}
\hline \hline 3 persons & 25.8 & 10.7 & 12.4 \\
\hline 4 persons & 13.4 & 1.9 & 9.1 \\
\hline$>4$ persons & 5.5 & 0.5 & 3.3 \\
\hline
\end{tabular}

2.1.2 Item selection for the initial version of the food waste-preventing behaviours scale: Even though no standardized scale to record the performance of relevant food waste-preventing behaviours was developed before, there are several collections of such behaviours proposed by other authors ${ }^{[6,7,12,14]}$. Thus, these collections were used to compile a baseline composition of nearly all conceivable relevant food waste-preventing behaviours. At the end of the collection process, the baseline composition contained more than 70 different behaviours. Considering the above-mentioned efficiency issue regarding the resulting scale (see section 1.2.2), further item selections were necessary in order to develop an applicable initial scale-version. Therefore, only "changeable" food waste-preventing behaviours were further selected for scale development: Thus, behaviours for those household members are not responsible (e.g. an unintended purchase of already spoiled food) were excluded. Additionally, it was tried to cover the whole class of relevant food waste-preventing behaviours (as already mentioned above, starting with preparation of grocery shopping, grocery shopping itself, preparation of food at home, storing of food at home to final discarding of food) with at least items as possible. At the end of this selection process, the initial version of the food waste-preventing behaviours scale contained 14 items (see Table 6 for an overview). All items were recorded by using a five-point Likert scale (ranging from 1 =" (almost) never" to 5 =" (almost) always"), introduced by questions, like: "Before grocery shopping, do you think carefully about the food you currently really need? This is what I do ..."

2.1.3 Data analyses procedure: As the central aim of the preliminary studies was to construct and examine an initial version of the food waste-preventing behaviours scale by understanding the underlying factor structure of the collected data as well as to reduce data sets to a more manageable size by identifying unnecessary items, an exploratory factor analysis was conducted for both data sets $^{[37]}$. Therefore, first analyses were done in order to check for sufficient data quality regarding important conditions for conducting these analyses (i.e. necessary sample sizes, Kaiser-Meyer-Olkin measure of sampling adequacy (KMO) and Bartlett's test of sphericity). Afterwards, the main analyses were conducted for both samples - using principle axis analysis as extraction method and calculated eigenvalues (Kaiser's criterion) as well as some theoretical preliminary considerations as relevant extraction criteria ${ }^{[32,37]}$. Finally, extracted factors were rotated by using an oblique rotation technique (Direct oblimin; Delta $=0$ ), because relations between the extracted factors were expected (due to the overall contribution of all relevant food waste-preventing behaviours to household food waste-prevention).

\subsection{Results of exploratory factor analyses}

2.2.1 Examining conditions for conducting exploratory factor analyses: Following ${ }^{[32]}$, for conducting an exploratory factor analysis, data of at least 200 people should be given. Thus with $N_{t 1}=217$ and $N_{t 2}=206$ both samples fulfilled this requirement as well as sufficient KMO-coefficients $(.74$ for 11 -data and .77 for $t 2$-data) and highly significant results $(\mathrm{p}<.01)$ of Bartlett's tests of sphericity. Thus, both data sets were adequate for conducting exploratory factor analyses.

2.2.2 Factor extraction, loadings and intercorrelations: Considering calculated eigenvalues within both data sets (Kaiser's criterion; see Table 2 for details) simultaneously did not lead to completely clear results: Considering t1 - eigenvalues, analyses proposed a five factors-extraction $(E V 1=3.97, E V 2=1.95, E V 3=1.70, E V 4=1.13, E V 5=1.05)$, while only a four factors-solution was proposed for $\mathrm{t} 2$-data $(E V 1=4.32, E V 2=1.90, E V 3=1.60, E V 4=1.12, E V 5=.89)$. Therefore, the final extraction decision was made in order to receive a solution as stable and as reproducible as possible. Thus, the four factor solution was preferred for both data sets. Based on the extraction of four factors, nearly $67 \%$ of variance could be explained in t 1 -data and $69 \%$ of variance in t 2 -data.

Table 2: Eigenvalues and explained variance of all possible factors, calculated in exploratory factor analysis conducted with t1- and t2-data sets

\begin{tabular}{|c|c|c|c|c|}
\hline \multirow{2}{*}{ Factor } & \multicolumn{2}{|c|}{ Eigenvalues } & \multicolumn{2}{c|}{ Explained variance } \\
\cline { 2 - 5 } & t1-sample & t2-sample & t1-sample & t2-sample \\
\hline 1 & 3.97 & 4.32 & 30.55 & 14.61 \\
\hline 2 & 1.95 & 1.90 & 15.00 & 12.30 \\
\hline 3 & 1.70 & 1.60 & 13.08 & 8.55 \\
\hline 4 & 1.13 & 1.11 & 8.66 & 6.83 \\
\hline 5 & 1.05 & .89 & 8.05 & 5.97 \\
\hline 6 & .79 & .78 & 6.07 & 5.42 \\
\hline 7 & .70 & .70 & 5.41 & 4.26 \\
\hline 8 & .54 & .55 & 4.18 & 3.45 \\
\hline 10 & .41 & .45 & 3.15 & 2.19 \\
\hline 11 & .32 & .29 & 1.90 & 1.82 \\
\hline 12 & .25 & .24 & 1.08 & .98 \\
\hline
\end{tabular}


As can be seen in Table 3, factor 1 (Avoiding spontaneous purchases due to different reasons) was represented by four items, characterized by high factor loadings in both data sets ( $.81, .83, .93$ and .81 for t1-data; $.83, .82, .94$ and .84 for t2-data). Factor 2 (Appropriate dealing with leftovers) was represented by two items, also characterized by high loadings (.98 and .96 for both data sets). Factor 3 (Appropriate dealing with excessed and expired, but (still) edible food) was also represented by two items, characterized by satisfying or at least acceptable loadings (.84 and .71 for t1-data; - .78 and -.58 for t2-data). Finally, factor 4 (Sufficient preparation of grocery shopping) was also represented by two other items, characterized by comparatively weak, but still acceptable loadings (.56 and .49 for t1-data; .64 and .45 for t2-data).

Table 3: Factor loadings of all items, calculated in exploratory factor analysis conducted with $\mathrm{t} 1$ - and t2-data sets

\begin{tabular}{|c|c|c|c|c|c|c|c|c|}
\hline \multirow[t]{2}{*}{ Items } & \multicolumn{2}{|c|}{$\begin{array}{l}\text { Factor 1: Avoiding } \\
\text { spontaneous purchas- } \\
\text { es due to different } \\
\text { reasons }\end{array}$} & \multicolumn{2}{|c|}{$\begin{array}{l}\text { Factor 2: Appro- } \\
\text { priate dealing with } \\
\text { leftovers }\end{array}$} & \multicolumn{2}{|c|}{$\begin{array}{l}\text { Factor 3: Appropriate } \\
\text { dealing with excessed } \\
\text { and expired, but (still) } \\
\text { edible food }\end{array}$} & \multicolumn{2}{|c|}{$\begin{array}{l}\text { Factor 4: Sufficient } \\
\text { Preparation of gro- } \\
\text { cery shopping }\end{array}$} \\
\hline & t1-sample & t2-sample & t1-sample & t2-sample & t1-sample & t2-sample & t1-sample & t2-sample \\
\hline $\begin{array}{l}\text { spontaneous purchases due to not } \\
\text { enough planning before grocery } \\
\text { shopping }(*)\end{array}$ & .82 & .83 & .01 & .02 & -.07 & .06 & .24 & .12 \\
\hline $\begin{array}{l}\text { spontaneous purchases due to spe- } \\
\text { cial offers / discounts (e. g. ,Take } 3 \text {, } \\
\left.\text { pay } 2 !^{*}\right)(*)\end{array}$ & .83 & .82 & .01 & .08 & .02 & -.07 & -.08 & -.02 \\
\hline $\begin{array}{l}\text { spontaneous purchases due to } \\
\text { promotion directly on-site (e.g. food } \\
\text { tasting). }(*)\end{array}$ & .93 & .94 & .00 & .05 & .07 & -.03 & -.01 & -.03 \\
\hline $\begin{array}{l}\text { spontaneous purchases due to no } \\
\text { smaller quantities available }\end{array}$ & .81 & .84 & .03 & -.02 & .06 & -.13 & -.01 & -.06 \\
\hline $\begin{array}{l}\text { Further processing/ consume of } \\
\text { leftovers }(* *)\end{array}$ & .01 & .02 & .98 & .96 & -.09 & .02 & -.03 & .02 \\
\hline Avoid discarding of leftovers( $(* *)$ & .04 & .05 & .98 & .96 & .01 & -.03 & -.04 & -.02 \\
\hline Avoid discarding of excessed food & .04 & .13 & .06 & .02 & .84 & -.78 & -.09 & -.10 \\
\hline $\begin{array}{l}\text { Avoid immediate discarding of } \\
\text { expired (but still edible) food(***) }\end{array}$ & .07 & .08 & -.11 & .19 & .71 & -.51 & .02 & .12 \\
\hline $\begin{array}{l}\text { Planning grocery shopping in } \\
\text { advance }\end{array}$ & .07 & .30 & -.04 & -.04 & -.08 & .12 & .56 & .64 \\
\hline Overview of food stocks at home & .03 & .07 & .03 & .03 & .23 & -.26 & .49 & .45 \\
\hline Frequency of grocery shopping & .06 & -.07 & -.01 & .08 & -.09 & -.03 & -.07 & .27 \\
\hline Time for grocery shopping & -.08 & -.09 & .04 & -.07 & .16 & -.15 & .16 & .39 \\
\hline $\begin{array}{l}\text { Usage of appropriate measures to } \\
\text { extend shelf life of food at home }\end{array}$ & .01 & -.02 & .18 & -.04 & .25 & -.34 & .26 & .08 \\
\hline
\end{tabular}

NOTE: $(*)$ Before conducting the factor analyses, these items were weighted with the item to record the general frequency of spontaneous purchases; $(* *)$ Before conducting the factor analyses, these items were weighted with the item to record the general frequency of preparing to much food for a meal; $\left({ }^{* *}\right)$ Before conducting the factor analyses, these items were weighted with the item to record the general frequency of expiring food.

As expected, results also revealed relevant, but varying intercorrelations between all extracted factors (see Table 4 for details): The strongest correlations $(r=.31, p<.01$ for $\mathrm{t} 1$-data; $r=.35, p<.01$ for 2 -data) were identified between factor 3 and factor 4. Only weak correlations ( $r=.09$, n.s. for both data sets) were identified between factor 2 and factor 4 , while all other correlations varied between $r=.14, p<.05$ and $r=.30, p<.01$. 
Household Food Waste-Prevention

Table 4: Factor intercorrelations, calculated in exploratory factor analysis conducted with $\mathrm{t} 1$ - and $\mathrm{t} 2$-data sets.

\begin{tabular}{|c|c|c|c|c|c|c|c|c|}
\hline \multirow[t]{2}{*}{ Factor } & \multicolumn{2}{|c|}{$\begin{array}{l}\text { Factor 1: Avoiding } \\
\text { spontaneous purchases } \\
\text { due to different reasons }\end{array}$} & \multicolumn{2}{|c|}{$\begin{array}{l}\text { Factor 2: Appropriate } \\
\text { dealing with leftovers }\end{array}$} & \multicolumn{2}{|c|}{$\begin{array}{l}\text { Factor 3: Appropriate } \\
\text { dealing with excessed and } \\
\text { expired, but (still) edible food }\end{array}$} & \multicolumn{2}{|c|}{$\begin{array}{l}\text { Factor 4: Sufficient } \\
\text { Preparation of gro- } \\
\text { cery shopping }\end{array}$} \\
\hline & t1-sample & t2-sample & t1-sample & t2-sample & t1-sample & t2-sample & t1-sample & t2-sample \\
\hline $\begin{array}{l}\text { Factor 1: Avoiding spon- } \\
\text { taneous purchases due to } \\
\text { different reasons }\end{array}$ & & & $.21 * *$ & $.27 * *$ & $.26^{* *}$ & $.29 * *$ & $.28 * *$ & $.30 * *$ \\
\hline $\begin{array}{l}\text { Factor 2: Appropriate deal- } \\
\text { ing with leftovers }\end{array}$ & $.21 * *$ & $.27 * *$ & & & $.14^{*}$ & $.25^{* *}$ & .09 & .09 \\
\hline $\begin{array}{l}\text { Factor 3: Appropriate } \\
\text { dealing with excessed and ex- } \\
\text { pired, but (still) edible food }\end{array}$ & $.26 * *$ & $.29 * *$ & $.14^{*}$ & $.25^{* *}$ & & & $.31 * *$ & $.35^{* *}$ \\
\hline $\begin{array}{l}\text { Factor 4: Sufficient Prepara- } \\
\text { tion of grocery shopping }\end{array}$ & $.28 * *$ & $.30 * *$ & .09 & .09 & $.31 * *$ & $.35^{* *}$ & & \\
\hline
\end{tabular}

$* * \mathrm{p}<.01 ; * \mathrm{p}<.05$

2.2.3 Appropriate dealing with remaining items and finalizing the initial version of the food waste-preventing behaviours scale: As already presented in Table 3, there were three remaining items, characterized by unclear results regarding the four extracted factors: As mentioned above, based on its eigenvalue, the extraction of a fifth factor was proposed for t1-data. But this possible factor was nearly completely represented by only one item - an item to record frequency of grocery shopping (initial factor loading: .75 for 11 -data). Because neither for $\mathrm{t} 1$-, nor for $\mathrm{t} 2$-data any other relevant loadings were found, this factor was not extracted. Simultaneously, the underlying item (to record frequency of grocery shopping) showed no relevant loadings on any of the extracted four factors - neither for $\mathrm{t}$-data, nor for $\mathrm{t} 2$-data. Therefore, this remaining item was excluded.

Another remaining item was initially used to record time spend for grocery shopping. But regarding the four extracted factors, this item showed no relevant loading for t1-data and only a marginal loading on factor 4 (.39) for t2-data. A comparable loading pattern was found for the last remaining item, that was initially used to record the usage of appropriate measures to extend shelf life of food at home: For t1-data no relevant factor loadings were identified, whereas for t2-data at least a marginal relevant loading on factor 3 (-.34) was found. To further decide how to deal with these two remaining items, middle product-moment-correlations[38] between these items and the four extracted factors were calculated (see Table 5). This procedure was chosen, because such correlations - at least at a minimum - should be given for an appropriate integration of these items into the full scale. Thereby, the item to record time spend on grocery shopping showed significant correlations with factor $3(r=.24, p<.01)$ and factor $4(r=.21, p<.01)$ in t1-data and nearly the same correlations were found for t2-data (factor 3: $r=.17, p<.05$ and factor 4: $r=.24, p<.01$ ). Instead, for the other item (to record usage of appropriate measures to extend shelf life of food at home) significant correlations were found with all extracted factors in t1-data (factor $1: r=.18, p<.01$; factor $2: r=.24, p<.01$; factor $3: r=.32, p<.01$; factor $4: r=.30, p$ $<.01)$. For 12 -data, highly significant correlations were found again for factor $3(r=.22, p<.01)$ and for factor $4(r=.21, p<.01)$.

Based on these results integrating only the item to record usage of appropriate measures to extend shelf life of food at home into the full scale was seen as useful, while the item to record time spend on grocery shopping was excluded.

Table 5: Correlations between the four extracted factors (during the exploratory factor analysis conducted with $\mathrm{t} 1$ - and t2-data sets) and the remaining items.

\begin{tabular}{|c|c|c|c|c|c|c|c|c|}
\hline \multirow[t]{2}{*}{ Factor } & \multicolumn{2}{|c|}{$\begin{array}{l}\text { Factor 1: Avoiding } \\
\text { spontaneous purchases } \\
\text { due to different reasons }\end{array}$} & \multicolumn{2}{|c|}{$\begin{array}{l}\text { Factor 2: Appro- } \\
\text { priate dealing with } \\
\text { leftovers }\end{array}$} & \multicolumn{2}{|c|}{$\begin{array}{l}\text { Factor 3: Appropriate } \\
\text { dealing with excessed and } \\
\text { expired, but (still) edible food }\end{array}$} & \multicolumn{2}{|c|}{$\begin{array}{l}\text { Factor 4: Sufficient } \\
\text { Preparation of grocery } \\
\text { shopping }\end{array}$} \\
\hline & t1-sample & t2-sample & t1-sample & t2-sample & t1-sample & t2-sample & t1-sample & t2-sample \\
\hline $\begin{array}{l}\text { Frequency of grocery } \\
\text { shopping }\end{array}$ & .03 & -.03 & .07 & .09 & .05 & .12 & .08 & .12 \\
\hline Time for grocery shopping & .02 & -.09 & .10 & -.02 & $.31 * *$ & $.17 *$ & $.21 * *$ & $.24 * *$ \\
\hline $\begin{array}{l}\text { using of appropriate mea- } \\
\text { sures to extend shelf life of } \\
\text { food at home }\end{array}$ & $.18^{* *}$ & .03 & $.24 * *$ & -.04 & $.32 * *$ & $.22 * *$ & $.30 * *$ & $.21 * *$ \\
\hline
\end{tabular}

** $\mathrm{p}<.01 ; * \mathrm{p}<.05$

\subsection{Examining relevant scale characteristics and discussion}

Following the exploratory factor analyses, relevant scale characteristics were calculated in order to further examine quality and applicability of the initial scale version as well as of its four subscales in both data sets (see Table 6). Therefore, mean values and standard deviations were calculated as relevant indications for item distribution. Additionally, reliability estimates were calculated for the full scale as well as for each subscale: Cronbach's Alpha estimates were calculated for subscales consisting of three or more items $^{[39]}$, while Spearman-Brown correlations were calculated as alternative reliability estimates for subscales consisting of two items $^{[40]}$. 
Household Food Waste-Prevention

OMMEga Publishers

Table 6: Relevant scale characteristics, calculated for the initial scale-version and its subscales with t1- and t2-data

\begin{tabular}{|c|c|c|c|c|c|c|c|}
\hline \multirow{2}{*}{ (Sub)scale/ item } & \multirow{2}{*}{$\begin{array}{l}\text { Number } \\
\text { of items }\end{array}$} & \multirow{2}{*}{\multicolumn{2}{|c|}{ Formulation }} & \multirow{2}{*}{ Mt1 (SD) } & \multirow{2}{*}{ Mt2 (SD) } & \multicolumn{2}{|c|}{ Reliability estimates } \\
\hline & & & & & & t1 & t2 \\
\hline $\begin{array}{l}\text { Initial version } \\
\text { of the food } \\
\text { waste-preventing }\end{array}$ & 11 & \multicolumn{2}{|c|}{ See below (items of all subscales) } & $3.48(.54)$ & $3.57(.56)$ & $\alpha=.81$ & $\alpha=.83$ \\
\hline $\begin{array}{l}\text { spontaneous } \\
\text { purchases due to } \\
\text { different reasons }\end{array}$ & 4 & $\begin{array}{l}\text { When you go grocery } \\
\text { shopping: Do you buy } \\
\text { more than you actually } \\
\text { need spontaneously? } \\
\text { This is what I do ... } \\
\text { What are the reasons } \\
\text { for these impulsive } \\
\text { purchases? }\end{array}$ & $\begin{array}{l}\text {.. not enough planning before } \\
\text { grocery shopping. }(*) \\
\text {.. special offers / discounts (e. g. } \\
\left.\text { „Take } 3 \text {, pay } 2 !^{*}\right) .\left({ }^{*}\right) \\
. \text { promotion directly on-site } \\
\text { (e.g. food tasting). }(*) \\
\text {.. no smaller quantities avail- } \\
\text { able. }(*)\end{array}$ & $2.76(.94)$ & $2.89(.96)$ & $\alpha=.92$ & $\alpha=.93$ \\
\hline $\begin{array}{l}\text { Appropriate } \\
\text { dealing with left- } \\
\text { overs after pre- } \\
\text { paring too much } \\
\text { food for meals } \\
\text { than currently } \\
\text { necessary }\end{array}$ & 2 & $\begin{array}{l}\text { Do you prepare too } \\
\text { much food for your } \\
\text { meals (so that there are } \\
\text { leftovers)? This is what } \\
\text { I do ... }\end{array}$ & $\begin{array}{l}\text { What do you do with (still) edi- } \\
\text { ble leftovers of your meals? } \\
\text { I process and/or consume the } \\
\text { leftovers later } \\
\text { What do you do with (still) edi- } \\
\text { ble leftovers of your meals? } \\
\text { I discard the leftovers finally. }(*)\end{array}$ & $2.72(.97)$ & $2.84(1.02)$ & $\mathrm{r}=.94$ & $\mathrm{r}=.94$ \\
\hline $\begin{array}{l}\text { Avoid discarding } \\
\text { of excess food } \\
\text { and the imme- } \\
\text { diate discarding } \\
\text { of expired (but } \\
\text { possibly still } \\
\text { edible) food }\end{array}$ & 2 & $\begin{array}{l}\text { What do you do with } \\
\text { (still) edible food, which } \\
\text { you can't (or don't want } \\
\text { to) consume? } \\
\text { How often does/ do your } \\
\text { food/ leftovers spoil or } \\
\text { pass its/ their freshness } \\
\text { date in your household? }\end{array}$ & $\begin{array}{l}\text { Finally, I discard the food. }(*) \\
\text { Do you discard food, which has } \\
\text { passed its freshness date, imme- } \\
\text { diately? This is what I do .... }\left(^{*}\right)\end{array}$ & $3.45(.97)$ & $3.57(.97)$ & $\mathrm{r}=.58$ & $\mathrm{r}=.51$ \\
\hline $\begin{array}{l}\text { Sufficient } \\
\text { Preparation of } \\
\text { grocery shopping }\end{array}$ & 2 & \multicolumn{2}{|c|}{$\begin{array}{l}\text { Before grocery shopping, do you think carefully about the } \\
\text { food you currently really need? This is what I do ... } \\
\text { Do you have a good overview of the stocks of food in your } \\
\text { household (that is, you know what is already there and how } \\
\text { long this food is edible)? That is what I know ... }\end{array}$} & $4.24(.63)$ & $4.28(.62)$ & $\mathrm{r}=.30$ & $\mathrm{r}=.37$ \\
\hline Storing of food & 1 & \multicolumn{2}{|c|}{$\begin{array}{l}\text { Do you use specific measure to extend the durability of } \\
\text { your food and/ or leftovers? Thist is what I do ... } \\
\text { Measure examples: } \\
\text { Covering or air-tight packaging of leftovers, a special } \\
\text { storage arrangement in the fridge, removing the packaging } \\
\text { foil of fruits and vegetables (which you often find in the } \\
\text { supermarket). }\end{array}$} & $4.26(.82)$ & $4.35(.90)$ & \multicolumn{2}{|c|}{ Not predictable } \\
\hline
\end{tabular}

NOTE: All item values were matched in a way that higher values represent a higher likelihood of household food waste-prevention (recoded items were marked with $(*))$. Generally, Cronbach's Alpha estimates were used as reliability measure for scales consisting of 3 or more items. For scales consisting of 2 items the Spearman-Brown correlation of both items was calculated as an alternative reliability measure (Eisinga et al., 2013).

Considering mean values of each subscale (ranging from 2.72 (.97) to 4.26 (.82) for t1-data and ranging from 2.84 (1.02) to 4.35 (.90) for t2-data), results suggest, that some relevant food waste-preventing behaviours are performed more frequently (e.g. behaviours related to sufficient preparation of grocery shopping) than others (e.g. behaviours related to appropriate dealing with leftovers). Consequently, some relevant food waste-preventing behaviours could be characterized by a higher number or stronger specific behavioral barriers ${ }^{[41]}$ than others - as already proposed ${ }^{[15]}$.

Considering scale reliability in both data sets, mostly high or at least sufficient reliability estimates were calculated for the full scale $\left(\alpha_{t 1}=.81\right.$ and $\left.\alpha_{t 2}=.83\right)$ as well as for its subscales with $\alpha_{t 1}=.92$ and $\alpha_{t 2}=.93$ for factor $1, r_{t 1}=.94 r_{t 2}=.94$ for factor $2, r_{t 1}$ $=.58$ and $\mathrm{r}_{\mathrm{t} 2}=.51$ for factor 3 and with $\mathrm{r}_{\mathrm{t} 1}=.30$ and $\mathrm{r}_{\mathrm{t} 2}=.37$ for factor $4^{[42,43]}$. Considering the comparatively low reliability estimates for factor 3 and 4, two different explanations seem possible: On the one hand, lower estimates could be the result of an inappropriate integration of two items into one superior factor. On the other hand, lower estimates could also be influenced by the chosen reliability estimation measure (for example, calculating e.g. retest reliability could lead to higher reliability values ${ }^{[39]}$. But only based on available data, no alternative reliability estimation measures could be calculated"(3)". Thus, by only considering preliminary data, no clear indications can be delivered to further examine both explanations. Strong associated with this point, another issue regarding the calculated reliability estimates should be mentioned: For the remaining item (to record usage of appropriate measures to extend shelf life of food at home), that was finally integrated into the full scale, and no reliability estimate could be calculated (because retest reliability estimations were not feasible, as already mentioned above). Thus, neither good nor bad statements can be made on the reliability of this item.

Taken together, both preliminary studies contributed successfully to the development of an initial version of the food waste-preventing behaviours scale. Simultaneously, the presented results also indicate the need of further development processes, especially regarding additional factor separations/ options to further extend as well as to consolidate the initial factorial structure of 
Household Food Waste-Prevention

the scale. Therefore, an additional study was conducted in order to contribute to these further development processes by examining a developed version of the food waste-preventing behavior scale.

\section{Examining a Developed Version of the Food Waste-Preventing Behavior Scale}

\subsection{Materials and methods}

3.1.1 Data collection and sample recruitment: The third assessment ( $\mathrm{t} 3$ ) to further extend as well as to consolidate the initial version of the food waste-preventing behaviours scale was conducted from spring to summer 2015. Therefore, a third online-survey was implemented in Lime Survey-software again. Participants were recruited in Germany, primary by using social networks (i.e. Facebook) and circular mails/ newsletters. Altogether, 348 people took part in the assessment. Out of those, 312 people completed the whole survey and formed the final - unfortunately, as well as the previous 11 - and $\mathrm{t} 2$-samples, not representative for German population (see Table 7 for details) - t3-sample.

Table 7: Socio-demographic characteristics of participants in the t3-assessment $(\mathrm{Nt3}=312)$ compared to German population.

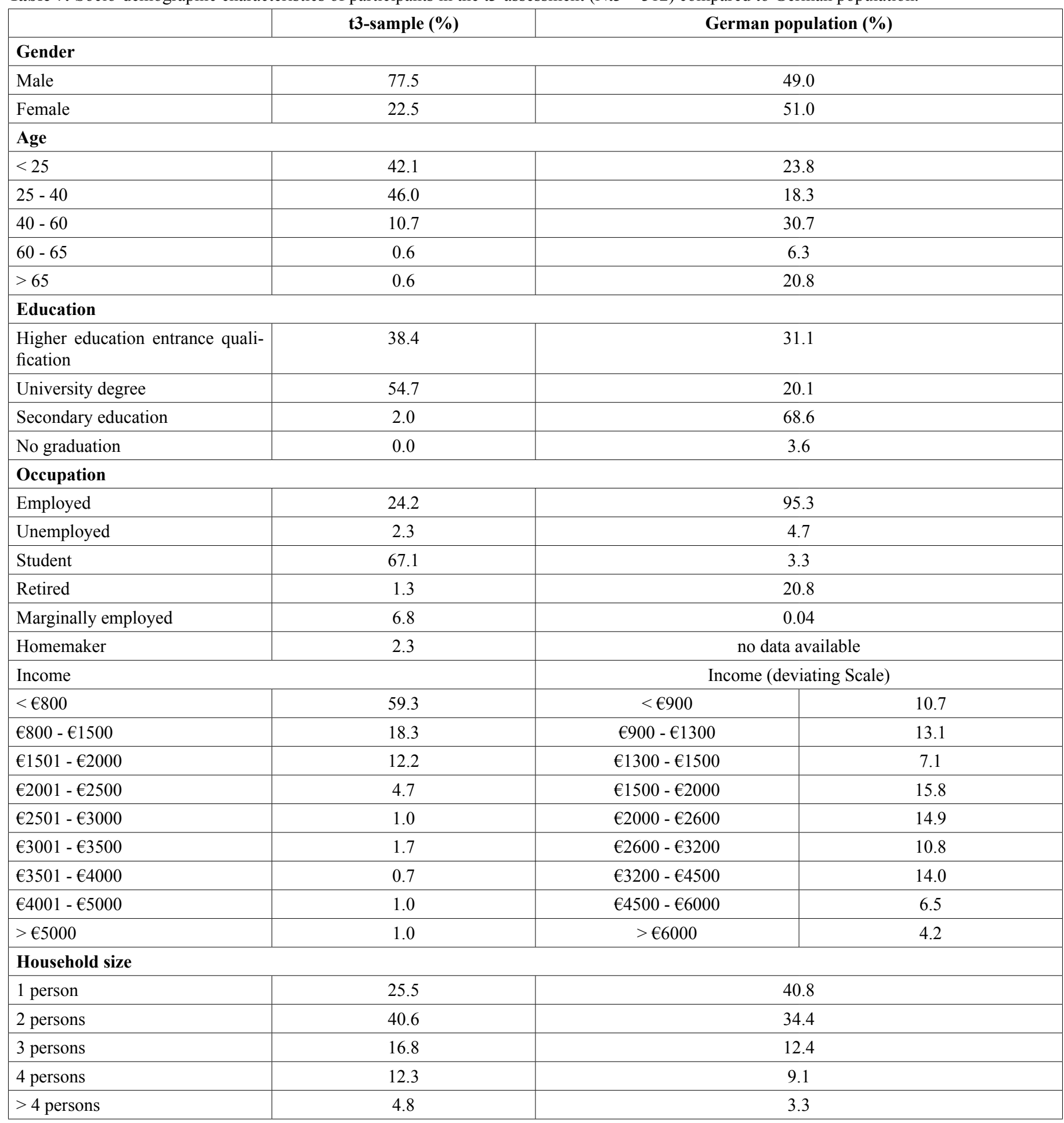


3.1.2 Further item selection for the developed food waste-preventing behaviours scale: In order to select additional items to further extend as well as to consolidate the initial factorial scale structure appropriately, the initially composed baseline composition of more than 70 conceivable relevant food waste-preventing behaviours (see section 2.1.2) was considered again. Thereby, the above-mentioned critical points regarding initial factorial structure of the initial scale version (especially referring to initial factors 3 and 4 as well as referring to the remaining single item; see section 2.3) were considered. Keeping these points in mind, finally, seven additional items were assessed as appropriate additions, primary representing additional food waste-preventing behaviours related to sufficient preparation of grocery shopping, appropriate dealing with expired and excessed, but (still) edible food as well as behaviours related to storing of food at home (see Table 11 for details). Thus, this extended scale-version consisted of 21 items. Again, all items were recorded by using a five-point Likert scale (ranging from 1 =" (almost) never" to 5 =" (almost) always"), introduced by questions, like: "Before grocery shopping, do you think carefully about the food you currently really need? This is what I do ..."

3.1.3 Data analysis procedure: Although, the preliminary studies identified some initial factor structure, also the third study's aim was to (further) understand (an extended) factor structure of the collected data Therefore, an exploratory factor analysis was conducted for $\mathrm{t} 3$-data again ${ }^{[37]}$. - starting with examining for sufficient data quality regarding important conditions for conducting these kind of analyses (necessary sample size, Kaiser-Meyer-Olkin measure of sampling adequacy (KMO) and Bartlett's test of sphericity). Afterwards, the main analysis was conducted nearly the same way as it was conducted for t1- and t2-data by using principle axis analysis as extraction method and an oblique rotation technique (Direct oblimin; Delta = 0; see again[32,37]. Because of the previous results and the mentioned assumptions regarding an extended factor structure of a developed scale, a combination of both was used as main the extraction criterion. Therefore, the extraction of seven factors (again, the initial factors 1 and 2 , whereas the initial factors 3 and 4 were assumed to be separated into two different factors respectively and one new factor representing storing of food) was predefined at the beginning of the analysis, while eigenvalues (Kaiser's criterion) were examined in order to identify relevant deviations of these assumptions.

\subsection{Results of the final exloratory factor analysis}

3.2.1 Examining conditions for conducting an exploratory factor analysis: Again in line ${ }^{[32]}$, with $N_{t 3}=312$ t3-data completely fulfilled the sample-size-requirement, as well as data revealed a sufficient KMO-coefficient (.78) and a highly significant result (p $<.01)$ of Bartlett's test of sphericity. Thus, t3-data sets were assessed as adequate for conducting an exploratory factor analysis.

3.2.2 Factor extraction, loadings and intercorrelations: As can be seen in Table 8, the predefined extraction of seven factors was nearly in line with the number of factors which would have been extracted based on calculated eigenvalues - at least one factor barely missed the 1.00-barrier. So, this criterion did not lead to strong deviations regarding the predefined number of to extracting factors. Therefore, the seven-factor solution, explaining more than $75 \%$ of all variance, was maintained.

Table 8: Eigenvalues and explained variance of all possible factors, calculated in exploratory factor analysis conducted with t3-data set.

\begin{tabular}{|c|c|c|}
\hline Factor & $\begin{array}{c}\text { Eigenvalues } \\
\text { t3-sample }\end{array}$ & $\begin{array}{c}\text { Explained variance } \\
\text { t3-sample }\end{array}$ \\
\hline 1 & 4.96 & 26.12 \\
\hline 2 & 2.26 & 12.05 \\
\hline 3 & 1.72 & 9.77 \\
\hline 4 & 1.47 & 8.87 \\
\hline 5 & 1.20 & 7.01 \\
\hline 6 & 1.03 & 5.81 \\
\hline 7 & .93 & 4.88 \\
\hline 8 & .74 & 3.93 \\
\hline 9 & .62 & 3.39 \\
\hline 10 & .58 & 3.25 \\
\hline 11 & .48 & 2.70 \\
\hline 12 & .46 & 2.43 \\
\hline 13 & .42 & 2.21 \\
\hline 14 & .33 & 1.87 \\
\hline 15 & .31 & 1.71 \\
\hline 16 & .25 & 1.43 \\
\hline 17 & .14 & 1.25 \\
\hline 18 & .11 & .72 \\
\hline
\end{tabular}


As can be seen in Table 9, factor 1 (Avoiding spontaneous purchases due to different reasons) was represented again by the same four items, characterized by high loadings (.82, .84, .96 and .77), as in the preliminary studies as well as factor 2 (Appropriate dealing with leftovers), which was also represented by the same two items as before, also characterized by high loadings (.94 and .89). As already expected, the initial factor representing appropriate dealing with excesses and expired, but (still) edible food, was now separated into two factors: Thereby, (new) factor 3 (Appropriate dealing with excessed, but (still) edible food) was represented by two items, characterized by high loadings (.70 and .72) as well as factor 4 (Appropriate dealing with expired food), which was also represented by two items, characterized by really high loadings (.94 and .90). Also in line with the previous expectations, factor 5 (Planning of grocery shopping in advance) was represented by three items, characterized by high or at least sufficient loadings $(.49, .87$ and .70$)$ and factor 6 (Sufficient overview on food stocks at home) was represented by two items, characterized by satisfactory loadings (.63 and .56). Finally, factor 7 (Usage of adequate measures to extend shelf-life of food at home) was represented by three remaining items. Consistent with the weakest eigenvalue of this factor, all items were characterized by at least acceptable, but comparatively weak loadings $(.49, .35$ and .47$)$.

Table 9: Factor loadings of all items, calculated in exploratory factor analysis conducted with t3-data set

\begin{tabular}{|c|c|c|c|c|c|c|c|}
\hline Items & $\begin{array}{l}\text { Factor 1: } \\
\text { Avoiding } \\
\text { spontaneous } \\
\text { purchases due } \\
\text { to different } \\
\text { reasons }\end{array}$ & $\begin{array}{l}\text { Factor 2: } \\
\text { Appropriate } \\
\text { dealing with } \\
\text { leftovers }\end{array}$ & $\begin{array}{l}\text { Factor 3: } \\
\text { Appropriate } \\
\text { dealing with } \\
\text { excessed, but } \\
\text { (still) edible } \\
\text { food }\end{array}$ & \begin{tabular}{|l|} 
Factor 4: \\
Appropri- \\
ate dealing \\
with ex- \\
pired food
\end{tabular} & $\begin{array}{l}\text { Factor 5: } \\
\text { Planning } \\
\text { of grocery } \\
\text { shop- } \\
\text { ping in } \\
\text { advance }\end{array}$ & $\begin{array}{l}\text { Factor 6: } \\
\text { Sufficient } \\
\text { overview on } \\
\text { food stocks } \\
\text { at home }\end{array}$ & $\begin{array}{l}\text { Factor } 7: \\
\text { Usage of ade- } \\
\text { quate measures } \\
\text { to extend shelf- } \\
\text { life of food at } \\
\text { home }\end{array}$ \\
\hline $\begin{array}{l}\text { General planning of grocery } \\
\text { shopping in advance }\end{array}$ & .02 & .02 & .49 & .09 & .26 & -.07 & .06 \\
\hline $\begin{array}{l}\text { General overview on food } \\
\text { stocks }\end{array}$ & .02 & .07 & -.10 & .08 & .63 & .04 & .20 \\
\hline $\begin{array}{l}\text { Using a shopping list in } \\
\text { general }\end{array}$ & -.08 & .02 & .86 & -.01 & -.17 & -.01 & .15 \\
\hline $\begin{array}{l}\text { Using the shopping list as } \\
\text { mandatory }\end{array}$ & .19 & -.01 & .70 & -.04 & .01 & .07 & -.15 \\
\hline $\begin{array}{l}\text { Spontaneous purchases due } \\
\text { to not enough planning be- } \\
\text { fore grocery shopping }(*)\end{array}$ & .82 & .03 & .09 & .00 & .00 & .06 & -.04 \\
\hline $\begin{array}{l}\text { Spontaneous purchases due } \\
\text { to special offers / discounts } \\
\text { (e. g. ,Take 3, pay } 2 !^{(“)}\left({ }^{*}\right)\end{array}$ & .84 & -.03 & -.03 & .01 & -.01 & -.01 & .06 \\
\hline $\begin{array}{l}\text { Spontaneous purchases due } \\
\text { to promotion directly on-site } \\
\text { (e.g. food tasting). }\left({ }^{*}\right)\end{array}$ & .96 & -.05 & .00 & .01 & .00 & .02 & .02 \\
\hline $\begin{array}{l}\text { Spontaneous purchases due } \\
\text { to no smaller quantities } \\
\text { available }\end{array}$ & .77 & .09 & -.01 & .00 & -.02 & -.07 & .04 \\
\hline $\begin{array}{l}\text { Avoid immediate discarding } \\
\text { of expired (but still edible) } \\
\text { food(***) }\end{array}$ & -.06 & .02 & -.01 & .72 & -.15 & .01 & .07 \\
\hline $\begin{array}{l}\text { Previous testing of expired } \\
\text { food }(* * *)\end{array}$ & .11 & -.02 & .02 & .66 & .19 & .01 & -.13 \\
\hline $\begin{array}{l}\text { Further processing/ consume } \\
\text { of leftovers }(* *)\end{array}$ & .05 & .93 & -.03 & .04 & .00 & .00 & .03 \\
\hline $\begin{array}{l}\text { Avoid discarding of left- } \\
\text { overs }(* *)\end{array}$ & -.01 & .89 & .02 & -.05 & .05 & .07 & -.04 \\
\hline $\begin{array}{l}\text { Avoid discarding of excessed } \\
\text { food }\end{array}$ & .08 & .23 & -.04 & .02 & -.02 & .72 & .00 \\
\hline $\begin{array}{l}\text { Sharing of excessed food } \\
\text { with other people }\end{array}$ & -.05 & -.05 & .01 & .01 & .02 & .70 & .03 \\
\hline $\begin{array}{l}\text { Usage of appropriate mea- } \\
\text { sures to extend shelf life of } \\
\text { food at home }\end{array}$ & -.03 & .22 & .23 & .04 & .06 & -.05 & .46 \\
\hline Storing food easily visible & .05 & .00 & .08 & -.02 & .08 & .18 & .35 \\
\hline $\begin{array}{l}\text { Knowing the exact location } \\
\text { of stored food }\end{array}$ & .00 & .05 & .02 & -.05 & .56 & .03 & .01 \\
\hline $\begin{array}{l}\text { Mentioning advices for opti- } \\
\text { mal food storing }\end{array}$ & .08 & .00 & -.05 & -.02 & .07 & .03 & .47 \\
\hline
\end{tabular}


NOTE: $\left(^{*}\right)$ Before conducting the factor analyses, these items were weighted with the item to record the general frequency of spontaneous purchases; $\left.{ }^{* *}\right)$ Before conducting the factor analyses, these items were weighted with the item to record the general frequency of preparing to much food for a meal; $(* * *)$ Before conducting the factor analyses, these items were weighted with the item to record the general frequency of expiring food.

As also expected, results of this final factor analysis also revealed relevant, but again varying intercorrelations between all seven extracted factors - except for factor 2 , which was characterized by only one significant, but weak correlation with factor $1(r=$ $.13, p<.05$; see Table 10 for details). Now, the strongest correlations were identified between factor 7 and factor $4(\mathrm{r}=.39, \mathrm{p}<.01$ and $r=.35, p<.01)$ as well as between factor 3 and factor $4(r=.37, p<.01$ and $r=.35, p<.01)$. Instead, the weakest correlations were identified between factor 5 and factor $6(r=.13, p<.05)$ as well as between factor 7 and factor $1(r=.14, p<.01)$.

Table 10: Factor intercorrelations, calculated in exploratory factor analysis conducted with t3-data set

\begin{tabular}{|c|c|c|c|c|c|c|c|}
\hline Factor & $\begin{array}{l}\text { Factor 1: } \\
\text { Avoiding } \\
\text { spontaneous } \\
\text { purchases due } \\
\text { to different } \\
\text { reasons }\end{array}$ & $\begin{array}{l}\text { Factor 2: } \\
\text { Appropriate } \\
\text { dealing with } \\
\text { leftovers }\end{array}$ & $\begin{array}{l}\text { Factor 3: } \\
\text { Appropriate } \\
\text { dealing with } \\
\text { excessed, but } \\
\text { (still) edible } \\
\text { food }\end{array}$ & $\begin{array}{l}\text { Factor 4: } \\
\text { Appropriate } \\
\text { dealing with } \\
\text { expired food }\end{array}$ & $\begin{array}{l}\text { Factor 5: } \\
\text { Planning } \\
\text { of grocery } \\
\text { shopping in } \\
\text { advance }\end{array}$ & $\begin{array}{l}\text { Factor 6: } \\
\text { Sufficient } \\
\text { overview on } \\
\text { food stocks at } \\
\text { home }\end{array}$ & $\begin{array}{l}\text { Factor } 7 \text { : } \\
\text { Usage of } \\
\text { adequate mea- } \\
\text { sures to extend } \\
\text { shelf-life of } \\
\text { food } t \text { home }\end{array}$ \\
\hline Factor 1 & & $.13^{*}$ & $.21 * *$ & $.27 * *$ & $.30 * *$ & $.30 * *$ & $.14 * *$ \\
\hline Factor 2 & $.13 *$ & & -.02 & .07 & .06 & .12 & .01 \\
\hline Factor 3 & $.21 * *$ & -.02 & & $.37 * *$ & .03 & $.22 * *$ & $.26^{* *}$ \\
\hline Factor 4 & $.27 * *$ & .07 & $.37 * *$ & & $.19 * *$ & $.34 * *$ & $.39 * *$ \\
\hline Factor 5 & $.30 * *$ & .06 & .03 & $.19 * *$ & & $.13 *$ & $.24 * *$ \\
\hline Factor 6 & $.31 * *$ & .12 & $.22 * *$ & $.34 * *$ & $.13 *$ & & $.37 * *$ \\
\hline Factor 7 & $.14^{* *}$ & .01 & $.26^{* *}$ & $.39 * *$ & $.24 * *$ & $.37 * *$ & \\
\hline
\end{tabular}

\subsection{Examining relevant scale characteristics and discussion}

As already done for the initial scale-version, relevant characteristics were calculated again for the developed scale-version in order to further examine the quality and applicability of the full scale as well as of its seven subscales (see Table 11). Therefore, the same measures (mean values, standard deviations and reliability estimates) were calculated for $\mathrm{t} 3$-data.

Table 11: Relevant scale characteristics, calculated for the developed scale-version and its subscales with $\mathrm{t} 3$-data.

\begin{tabular}{|c|c|c|c|c|c|}
\hline (Sub)scale/ item & $\begin{array}{l}\text { Number } \\
\text { of items }\end{array}$ & \multicolumn{2}{|l|}{ Formulation } & Mt1 (SD) & $\begin{array}{l}\text { Reliability } \\
\text { estimates }\end{array}$ \\
\hline $\begin{array}{l}\text { Developed version of the } \\
\text { food waste-preventing } \\
\text { aviours scale }\end{array}$ & 18 & \multicolumn{2}{|l|}{ See below (items of all subscales) } & $3.45(.52)$ & $\alpha=.81$ \\
\hline $\begin{array}{l}\text { spontaneous purchases } \\
\text { due to different reasons }\end{array}$ & 4 & $\begin{array}{l}\text { When you go grocery shopping: } \\
\text { Do you buy more than you actu- } \\
\text { ally need spontaneously? This is } \\
\text { what I do ... } \\
\text { What are the reasons for these } \\
\text { impulsive purchases? }\end{array}$ & $\begin{array}{l}\text {.. not enough planning before grocery } \\
\text { shopping. }(*) \\
\text {.. special offers / discounts (e. g. } \\
\left.\text { „Take } 3 \text {, pay } 2 !{ }^{*}\right) .(*) \\
. . \text { promotion directly on-site (e.g. food } \\
\text { tasting). }(*) \\
. . \text { no smaller quantities available. }(*)\end{array}$ & $2.81(.98)$ & $\alpha=.91$ \\
\hline $\begin{array}{l}\text { Appropriate dealing } \\
\text { with leftovers after } \\
\text { preparing too much food } \\
\text { for meals than currently } \\
\text { necessary }\end{array}$ & 2 & $\begin{array}{l}\text { Do you prepare too much food } \\
\text { for your meals (so that there are } \\
\text { leftovers)? This is what I do ... }\end{array}$ & $\begin{array}{l}\text { What do you do with (still) edible } \\
\text { leftovers of your meals? } \\
\text { I process and/or consume the leftovers } \\
\text { later } \\
\text { What do you do with (still) edible } \\
\text { leftovers of your meals? } \\
\text { I discard the leftovers finally. }(*)\end{array}$ & $2.77(.90)$ & $\mathrm{r}=.55$ \\
\hline $\begin{array}{l}\text { Appropriate dealing } \\
\text { with excessed, but (still) } \\
\text { edible food }\end{array}$ & 2 & $\begin{array}{l}\text { What do you do with (still) } \\
\text { edible food, which you can't (or } \\
\text { don't want to) consume? }\end{array}$ & $\begin{array}{l}\text { Finally, I discard the food. }(*) \\
\text { I share excessed food with other } \\
\text { persons (family, friend etc.) or (social) } \\
\text { institutions. }\end{array}$ & $3.27(1.18)$ & $\mathrm{r}=.54$ \\
\hline $\begin{array}{l}\text { Appropriate dealing } \\
\text { with expired food }\end{array}$ & 2 & $\begin{array}{l}\text { How often does/ do your food/ } \\
\text { leftovers spoil or pass its/ their } \\
\text { freshness date in your house- } \\
\text { hold? } \\
\text { What do you do with expired } \\
\text { food? }\end{array}$ & $\begin{array}{l}\text { I discard food, which has passed its } \\
\text { freshness date, immediately. }(*) \\
\text { I initially test the food (by smelling, } \\
\text { tasting etc.) and afterwards I decide, } \\
\text { to consume or to discard. }\end{array}$ & $3.51(.91)$ & $\mathrm{r}=.86$ \\
\hline
\end{tabular}




\begin{tabular}{|c|c|c|c|c|}
\hline $\begin{array}{l}\text { Planning of grocery } \\
\text { shopping in advance }\end{array}$ & 3 & $\begin{array}{l}\text { Before grocery shopping, do you think carefully about the food you cur- } \\
\text { rently really need? This is what I do ... } \\
\text { Before grocery shopping, do you write a shopping list? This is what I do } \\
\ldots \\
\text { Do you treat shopping lists as mandatory? That means, you only buy food } \\
\text { that was listed and no other food. This is what I do ... }\end{array}$ & $3.67(.94)$ & $\alpha=.73$ \\
\hline $\begin{array}{l}\text { Sufficient overview on } \\
\text { food stocks at home }\end{array}$ & 2 & $\begin{array}{l}\text { Do you have a good overview of the stocks of food in your household } \\
\text { (that is, you know what is already there and how long this food is edible)? } \\
\text { That is what I know ... } \\
\text { Do you know exactly the location of all food, you are storing at home? } \\
\text { That is what I know ... }\end{array}$ & $4.37(.65)$ & $\mathrm{r}=.40$ \\
\hline $\begin{array}{l}\text { Usage of adequate mea- } \\
\text { sures to extend shelf-life } \\
\text { of food at home }\end{array}$ & 1 & $\begin{array}{l}\text { Do you use specific measure to extend the durability of your food and/ or } \\
\text { leftovers? This is what I do ... } \\
\text { Measure examples: } \\
\text { Covering or air-tight packaging of leftovers, a special storage arrangement } \\
\text { in the fridge, removing the packaging foil of fruits and vegetables (which } \\
\text { you often find in the supermarket). } \\
\text { Do you store food at home easily visible (e.g. in first line in the fridge or } \\
\text { in cupboards)? This is what I do ... } \\
\text { Do you mention advices for optimal storing (e.g. printed on food packag- } \\
\text { ing) when storing your food at home? This is what I do .. }\end{array}$ & $3.74(.79)$ & $\alpha=.55$ \\
\hline
\end{tabular}

In line with previous results, considering mean values of each subscale (ranging from 2.77 (.90) to 4.37 (.65)) still indicates general differences in performance frequency of the examined food waste-preventing behaviours - further supporting made assumptions regarding different behavior difficulty because of different amounts of specific behavioural barriers.

Considering calculated reliability estimates, data revealed really high or at least good reliability estimates for the full scale as well as for nearly all subscales ${ }^{[43,44]}$ of the developed food waste-preventing behaviours scale. Especially regarding newly built subscales for planning of shopping in advance, sufficient overview on food stocks at home, appropriate dealing with expired food and for appropriate dealing with excessed, but (still) edible food, reliability estimates were satisfying. Only one subscale was characterized by an at least acceptable reliability estimate - usage of measures to extend food's shelf life at home. Thus, the overall aim of this final study (i.e. further extending and consolidating the initial factor structure of the scale) was generally reached.

\section{General Discussion}

\subsection{Summary}

The central aim of the current paper was to propose an efficient (online) tool/ measuring instrument for recording self-reported performances of several relevant food waste-preventing behaviours. Starting with developing and examining an initial scale-version consisting of 14 items, characterized by a four factor solution, finally, a more comprehensive developed scale-version - consisting of 21 items - could be created. Considering relevant characteristics, the developed food waste-preventing behaviours scale seems to be such an efficient and satisfying (online) tool/ measuring instrument that was aimed. Thus, this scale could actually be used by existing and future food waste-preventing initiatives for increasing the relevance of their provided action knowledge in order to sustainably promote (further) household food waste-prevention. But the application field of the proposed scale should not be limited only on a practical area. Instead, the scale could also be used as an appropriate research tool, for example, when conducting science based intervention studies as it was done, for example, by Schmidt (2016).

\subsection{Limitations and implications for future research}

Although, the presented results indicated reaching relevant research goals, there are some limitations that should also be mentioned. Thereby, one limitation refers to the exclusive use of self-reported measures to record the performance of relevant food waste-preventing behaviours: As a general limitation associated with self-report measures, possible response biases - especially referring to social desirability - having negative impacts on the data quality ${ }^{[45,46]}$ cannot be excluded.

Furthermore, generalizing current results is restricted referring to their transferability on other samples and populations. As shown above, all studies were conducted with convenience and not representative (for German population) samples, mainly consisting of well-educated, young and female students characterized by low incomes.

Finally and maybe not completely seen as a limitation, but as an opportunity for future research: Although the developed scale is characterized by primary satisfying characteristics (especially regarding calculated reliability estimates), further scale improvements could (still) be indicated - especially regarding the seventh subscale to record usage of measures to extend food's shelf life at home. For example, by examining alternative item formulations, creation of additional useful items or possibly additional factors/ subscales or further scale characteristic estimations (other reliability estimation measures ${ }^{[39]}$. Additionally, conducting confirmatory factor analyses in order to validate the proposed factor structure would be another appropriate objective for future research. 


\section{Conclusion}

So, based on the presented results, an efficient (online) tool/ measuring instrument was developed, that could be easily used by currently existing or future food waste-prevention initiatives to further promote household food waste-prevention by restricting provided action knowledge on these a person (still) not perform (sufficiently). Therefore, the perceived relevance of the provided information will increase, expected to increase probability of consistent and durable improvements of relevant food waste-preventing behaviours. Consequently, such improvements will probably result in fewer amounts of household food waste and so, in relevant reductions of its negative consequences on our environment.

\section{Acknowledgements}

(1) Similar assumptions concerning household's energy saving-promotion by providing appropriate action knowledge were made ${ }^{[47]}$.

(2) These two assessments were part of a superior research project focusing on household food waste-prevention ${ }^{[20]}$.

(3) Since both assessments were part of a superior research project to further examine household food waste-prevention by conducting an intervention for its promotion, correlations between $\mathrm{t} 1$ - and $\mathrm{t} 2$-data could not be used to calculate retest reliability estimations.

Back to top: "(1)", "(2)", "(3)"

\section{References}

1. Buchner, B., Fischler, C., Gustafson, E., et al. Food waste: causes, impacts and proposals. (2012).

2. Gustavsson, J., Cederberg, C., Sonesson, U., et al. Global food losses and food waste. (2011) Food and agriculture organisation of the nations.

3. HLPE. Food losses and waste in the context of sustainable food systems. (2014) A report by the High Level Panel of Experts on Food Security and Nutrition of the Committee on World Food Security.

4. Lipinski, B., Hanson, C., Lomax, J., et al. Reducing food loss and waste. (2013) Reducing food lose and waste.

5. Monier, V., Mudgal, S., Escalon, V., et al. Preparatory Study on Food Waste Across EU 27. (2010).

6. Priefer, C., Jörissen, J., Bräutigam, K.-R. Food waste prevention in Europe-A cause-driven approach to identify the most relevant leverage points for action. (2016) Resources, Conservation and Recycling 109: 155-165.

7. Stuart, T. (2009). Waste: uncovering the global food scandal: WW Norton \& Company.

8. Thyberg, K. L., Tonjes, D. J. Drivers of food waste and their implications for sustainable policy development. (2016) Resources, Conservation and Recycling 106: 110-123.

9. Food wastage footprint. Impacts on natural resources. (2013) Food and Agriculture Organization of the United Nations (FAO). Summary Report. 10. Lucifero, N. Food Loss and Waste in the EU Law between Sustainability of Well-being and the Implications on Food System and on Environment. (2016) Agriculture and Agricultural Science Procedia 8: 282-289.

11. Parfitt, J., Barthel, M., Macnaughton, S. Food waste within food supply chains: quantification and potential for change to 2050. (2010) Philos Trans R Soc Lond B Biol Sci 365(1554): 3065-3081.

12. WWF Schweiz [Switzerland]. (2012). Lebensmittelverluste in der Schweiz - Ausmaß und Handlungsoptionen.

13. Kranert, M., Hafner, G., Barabosz, J., et al. Ermittlung der weggeworfenen Lebensmittelmengen und Vorschläge zur Verminderung der Wegwerfrate bei Lebensmitteln in Deutschland. (2012).

14. Farr-Wharton, G., Foth, M., Choi, J. H. J. Identifying factors that promote consumer behaviours causing expired domestic food waste. (2014) Journal of Consumer Behaviour 13(6): 393-402.

15. Quested, T. E., Marsh, E., Stunell, D., et al. Spaghetti soup: the complex world of food waste behaviours. (2013) Resources, Conservation and Recycling 79: 43-51.

16. Graham-Rowe, E., Jessop, D. C., Sparks, P. Identifying motivations and barriers to minimising household food waste. (2014) Resources, Conservation and Recycling 84: 15-23.

17. Graham-Rowe, E., Jessop, D. C., Sparks, P. Predicting household food waste reduction using an extended theory of planned behaviour. (2015) Resources, Conservation and Recycling 101: 194-202.

18. Parizeau, K., von Massow, M., Martin, R. Household-level dynamics of food waste production and related beliefs, attitudes, and behaviours in Guelph, Ontario. (2015) Waste Manag 35: 207-217.

19. Visschers, V. H., Wickli, N., Siegrist, M. Sorting out food waste behaviour: A survey on the motivators and barriers of self-reported amounts of food waste in households. (2016) Journal of Environmental Psychology 45: 66-78.

20. Watson, M., Meah, A. Food, waste and safety: negotiating conflicting social anxieties into the practices of domestic provisioning. (2013) The Sociological Review 60(S2): 102-120.

21. Schmidt, K. Explaining and promoting household food waste-prevention by an environmental psychological based intervention study. (2016) Resources, Conservation and Recycling 111: 53-66.

22. Mondéjar-Jiménez, J.A., Ferrari, G., Secondi, L., et al. (in press). From the table to waste: An exploratory study on behaviour towards food waste of Spanish and Italian youths. (2016) J Cleaner Production.

23. Neff, R. A., Spiker, M. L., Truant, P. L. Wasted Food: US Consumers' Reported Awareness, Attitudes, and Behaviours. (2015) PloS one 10(6): e0127881.

24. Abrahamse, W., \& Matthies, E. Informational strategies to promote pro environmental behaviour: Changing knowlegde, awareness and attitudes. In L. Steg, A. van den Berg, \& J. de Groot (Eds.), Environmental psychology: An introduction (pp. 224-231). (2012) Southern Gate, Chichester: Wiley.

25. Homburg, A., Matthies, E. Umweltpsychologie: Umweltkrise, Gesellschaft und Individuum: (1998) Beltz Juventa.

26. Mack, B. Energiesparen fördern durch psychologische Intervention: (2007) Waxmann Verlag.

27. Klöckner, C. A. The psychology of pro-environmental communication - going beyond standard information strategies. (2015) Houndmills, Basingstoke, Hampshire, New York: Palgrave Publishing.

28. Petty, R. E., Cacioppo, J. T. The elaboration likelihood model of persuasion. (1986) Advances in Experimental Social Psychology 19: 123-205. 
29. Petty, R. E., Wegener, D. T. The Elaboration Likelihood Model: Current Status and Controversies. (1999) Dual process theories in social psychology New York: Guilford Press: 41-72.

30. Chaiken, S. The heuristic model of persuasion. Paper presented at the Social influence: (1987) the ontario symposium.

31. Chaiken, S., Liberman, A., Eagly, A. H. Heuristic and Systematic Information Processing within and beyond the Persuasion Context. In J. S. Uleman \& J. A. Bargh (Eds.). (1989). Unintended thought (pp. 212-254). New York, London: Guilford Press.

32. Eagly, A. H., \& Chaiken, S. The psychology of attitudes. (1993) Harcourt Brace Jovanovich College Publishers.

33. Bühner, M. Einführung in die Test-und Fragebogenkonstruktion. München: (Pearson Deutschland GmbH).

34. Chaiken, S. (1980). Heuristic versus systematic information processing and the use of source. versus message cues in persuasion. (2006) Journal of Personality and Social Psychology 39(5): 752-766.

35. Petty, R. E., Wegener, D. T. Attitude Change: Multiple Roles for Persuasion Variables. In D. T. Gilbert, S. T. Fiske, \& G. Lindzey (Eds.), (1998).

The Handbook of Social Psychology (pp. 323-390). New York: Jane Valcunas.

36. Statistisches, Bundesamt. Privathaushalte und Haushaltsmitglieder. (2014).

37. Statistisches Bundesamt. (2015a). Die Generation 65+ in Deutschland.

38. Statistisches Bundesamt. (2015b). Statistisches Jahrbuch. Deutschland und internationales.

39. Field, A. Discovering statistics using IBM SPSS statistics (edition 4). (2013) Los Angeles u.a: 952.

40. Bortz, J., Döring, N. Forschungsmethoden und Evaluation: für Human-und Sozialwissenschaftler. (2006) Heidelberg.

41. Eisinga, R., Grotenhuis, M. T., Pelzer, B. The reliability of a two-item scale: Pearson, Cronbach, or Spearman-Brown? (2013) International journal of public health 58(4): 637-642.

42. McKenzie Mohr, D. Fostering sustainable behavior: An introduction to community-based social marketing. (2008) Gabriola Island: New Society Publishers.

43. George, D., Mallery, P. SPSS for Windows step by step: A simple guide and reference edition (11.0) update. (2003) Boston: Allyn \& Bacon. 44. Gliem, J. A., Gliem, R. R. Calculating, interpreting, and reporting Cronbach's alpha reliability coefficient for Likert-type scales. (2003) Midwest Research to Practice Conference in Adult, Continuing, and Community Education.

45. Krumpal, I. Determinants of social desirability bias in sensitive surveys: a literature review. (2013) Quality \& Quantity 47(4): $2025-2047$.

46. Tourangeau, R., Yan, T. Sensitive questions in surveys. (2007) Psychological Bulletin 133(5): 859-883.

47. Nachreiner, M., Matthies, E. Enhancing informational strategies for supporting residential electricity saving: Identifying potential and household characteristics in Germany. (2016) Energy Research \& Social Science 11: 276-287.

\section{Online ISSN: 2377-0619}

Journal Title: International Journal Food and Nutritional Science Journal Short Name: Int J Food Nutr Sci

\section{Ommega Online Publishers}

E-mail: editor.foodscience@ommegaonline.com Website: www.ommegaonline.org 